\title{
FAKTOR-FAKTOR YANG MEMPENGARUHI VOLUME PEMBIAYAAN BERBASIS BAGI HASIL DAN RASIO BOPO PADA PERBANKAN SYARIAH
}

\author{
WIRMAN \\ Universitas Singaperbangsa Karawang \\ wirmanmunaraja@gmail.com
}

\begin{abstract}
The objective of the study is to obtain empirical evidence of factors affecting the volume of financing based on cost sharing and the ratio of BOPO to Sharia Banking. The number of population in this study is the number of units analyzed consisting of all Islamic banks in Indonesia either BUS, UUS or BPRS. The method of selecting the sample used is purposive sampling. Testing using multiple regression analysis. The result of the research shows that there is influence of DPK to funding based on the result of mudharabah and musyarakah in both syariah banking institution in Indonesia. There is an effect of earnings on financing based on the sharing of mudharabah and musharaka in both Islamic banking institutions in Indonesia. There is no effect of NPF/non-performing financing on Mudharabah-based finance sharing in BUS in Indonesia. However, the NPF has a significant effect on mudharabah-based revenue sharing at the SRB. There is no effect of NPF / non-performing financing on the musharaka-based financing of the BUS in Indonesia. However, the NPF has a significant effect on the musharaka-based sharing financing in the SRB. There is no effect of interest rate on cost sharing based on mudharabah and musyarakah result in sharia banking in Indonesia. There is a funding effect based on the results of mudharabah and musyarakah on the ratio of BOPO in both Islamic banking institutions in Indonesia.
\end{abstract}

Keywords: Volume financing, cost sharing, BOPO, Banking, Syariah.

Abstrak: Tujuan penelitian adalah untuk mendapatkan bukti empiris faktor-faktor yang mempengaruhi volume pembiayaan berbasis bagi hasil dan rasio BOPO pada Perbankan Syariah. Jumlah Populasi dalam penelitian ini adalah jumlah unit yang dianalisis terdiri dari seluruh perbankan syariah yang ada di Indo-nesia baik BUS, UUS maupun BPRS.Metode pemilihan sampel yang digunakan adalah purposive sampling. Pengujian menggunakan analisis regresi berganda. Hasil penelitian menunjukkan bahwa terdapat pengaruh DPK terhadap pembiayaaan berbasis bagi hasil mudharabah dan musyarakah pada kedua lembaga perbankan syariah di Indonesia. Terdapat pengaruh laba terhadap pembiayaaan berbasis bagi hasil mudharabah dan musyarakah pada kedua lembaga perbankan syariah di Indonesia. Tidak terdapat pengaruh NPF/pembiayaan macet terhadap pembiayaan berbasis bagi hasil mudharabah pada BUS di Indonesia. Akan tetapi NPF berpengaruh signifikan terhadap pem-biayaaan berbasis bagi hasil mudharabah pada BPRS. Tidak terdapat pengaruh NPF/pembiayaan macet terhadap pembiayaan berbasis bagi hasil musyarakah pada BUS di Indonesia. Akan tetapi NPF berpengaruh signifikan terhadap pembiayaan berbasis bagi hasil musyarakah pada BPRS. Tidak 
terdapat pengaruh suku bunga terhadap pembiayaaan berbasis bagi hasil mudharabah dan musyarakah pada perbankan syariah di Indonesia. Terdapat pengaruh pembiayaaan berbasis bagi hasil mudharabah dan musyarakah terhadap rasio BOPO pada kedua lembaga perbankan syariah di Indonesia.

Kata kunci: Volume pembiayaan, bagi hasil, BOPO, Perbankan, Syariah.

\section{PENDAHULUAN}

Prinsip bagi hasil merupakan karakteristik umum dan landasan dasar operasional bank syariah. Akad utama dalam perbankan syari'ah adalah pembiayaan dengan akad mudharabah dan pembiayaan dengan akad musyarakah. Akad bagi hasil inilah yang membedakan dengan perbankan konvensional secara keseluruhan. Persoalannya adalah pembiayaan berbasis bagi hasil seharusnya tumbuh lebih mendominasi, jika dibandingkan dengan pembiayaan akad jual beli atau akad murabahah, karena pada dasarnya salah satu misi penting yang diemban oleh bank syariah adalah mengentaskan kemiskinan, oleh karena itu bank harus berusaha untuk lebih meningkatkan pembiayaan secara mudharabah dan musyarakah. Dengan alasan, karena lewat pembiayaan inilah salah satu cara untuk meningkatkan perekonomian masyarakat, hal ini juga dikarenakan pembiayaan lewat mudharabah dan musyarakah adalah pembiayaan jangka panjang, sehingga implikasi terhadap perekonomian juga sangat besar. Tetapi kenyataannya pembiayaan berbasis bagi hasil berada pada posisi yang sangat tidak menguntungkan, yaitu dengan posisi pertumbuhan sangat jauh tertinggal di bawah pembiayaan murabahah.

Tabel 1 Pertumbuhan Pembiayaan Perbankan Syariah.

Bank Umum Syariah dan Unit Usaha Syariah (milyar rupiah)

\begin{tabular}{lrrrrr}
\hline Pembiayaan & Des 10 & Des 11 & Des 12 & Des 13 & Des 14 \\
\cline { 1 - 5 } Murabahah & 37.508 & 56.365 & 88.004 & 110.565 & 117.371 \\
Mudharabah & 8.631 & 10.229 & 12.023 & 13.625 & 14.354 \\
Musyarakah & 14.624 & 18.960 & 27.667 & 39.874 & 49.387 \\
Lainnya & 7.663 & 17.101 & 19.811 & 20.295 & 18.218 \\
\cline { 2 - 3 }
\end{tabular}

Sumber : Statistik Perbankan Syariah, Desember 2014 
Tabel 2 Pertumbuhan Pembiayaan Perbankan Syariah.

Bank Pembiayaan Rakyat Syariah

(juta rupiah)

\begin{tabular}{lrrrrr}
\hline \multirow{2}{*}{ Pembiayaan } & Des 10 & \multicolumn{1}{c}{ Des 11 } & \multicolumn{1}{c}{ Des 12 } & Des 13 & \multicolumn{1}{c}{ Des 14 } \\
\cline { 1 - 5 } Murabahah & 1.621 .526 & 2.154 .494 & 2.854 .646 & 3.546 .361 & 3.965 .543 \\
Mudharabah & 65.471 & 75.807 & 99.361 & 106.851 & 122.467 \\
Musyarakah & 217.954 & 246.796 & 321.131 & 426.528 & 567.658 \\
Lainnya & 155.486 & 198.833 & 278.381 & 353.752 & 349.241 \\
\hline
\end{tabular}

Sumber : Statistik Perbankan Syariah, Desember 2014

Dari ketiga macam pertumbuhan pembiayaan perbankan syariah (Bank Umum Syariah dan Unit Usaha Syariah) yang dilihat dari tabel 1, secara rata-rata pertumbuhan dari pembiayaan mudharabah dan musyarakah dalam lima tahun terakhir tidak ada melebihi pembiayaan murabahah. Bila dibandingkan secara rata-rata pertumbuhan murabahah berbanding mudharabah adalah sama dengan 6,9 berbanding 1 . Sedangkan perbandingan secara rata-rata pertumbuhan murabahah berbanding musyarakah adalah sama dengan 2,7 berbanding 1 . Artinya fenomena perkembangan pembiayaan murabahah (jual beli) yang demikian cepat dibandingkan dengan pembiayaan mudhara-bah dan musyarakah, sehingga pembiayaan murabahah lebih mendominasi pembiayaan selama 5 tahun berturut-turut yaitu dari 2010-2014. Data yang disajikan tersebut merupakan kondisi rata-rata yang merefleksikan portofolio perbankan syariah nasional secara keseluruhan, dan bukan terjadi da-lam satu dua kasus bank syariah yang ada, hal ini menggambarkan kecenderungan tidak seimbangnya keiatan di sektor moneter atau keuangan dan sektor riil.Artinya akad murabahah masih mendominasi pertumbuhan pembiayaannya selama 5 tahun berturut-turut yaitu dari 2010-2014. Hal ini menjadi pertanyaan terkait dengan faktor-faktor yang menyebabkan tersendatnya perkembangan pembiayaan mudharabah dan musyarakah.

Pertumbuhan pembiayaan pada Bank Pembiayaan Rakyat Syariah (BPRS) yang dapat dilihat dari tabel 2, secara rata-rata pertumbuhan dari pembiayaan mudharabah dan musyarakah dalam lima tahun terakhir tidak ada melebihi pembiayaan murabahah. Bila dibandingkan secara rata-rata partum-buhan murabahah berbanding mudharabah adalah sama dengan 30 berbanding 1 . Sedangkan perbandingan secara rata-rata pertumbuhan murabahah berbanding musyarakah adalah sama dengan 7,9 berbanding 1 . Artinya akad murabahah masih mendominasi pertumbuhan pembia-yaannya selama 5 tahun berturut-turut yaitu dari 2010-2014. Total pembiayaan dengan akad bagi hasil tidak pernah lebih dari setengah total pembiayaan dengan akad murabahah. Pembiayaan dengan akad bagi hasil diharapkan lebih menggerakan sektor riil, karena menutup kemungkinan disalurkannya dana pada kepentingan konsumtif dan hanya pada usaha produktif.

Input dari pembiayaan adalah akad berbasis bagi hasil, dan outputnya adalah imbal hasil yang dibagikan.Mengindikasikan imbal hasil pada akad bagi hasil pada perbankan syariah lima tahun terakhir. 
Tabel 3 Imbal hasil dan margin pembiayaan pada perbankan syariah. Bank Umum Syariah dan Unit Usaha Syariah

\begin{tabular}{|c|c|c|c|c|c|}
\hline $\begin{array}{l}\text { Tahun } \\
\text { Pembiayaan }\end{array}$ & Des 10 & Des 11 & Des 12 & Des 13 & Des 14 \\
\hline Murabahah & $15,30 \%$ & $14,72 \%$ & $13,69 \%$ & $13,18 \%$ & $13,20 \%$ \\
\hline Mudharabah & $17,39 \%$ & $16,05 \%$ & $14,90 \%$ & $14,40 \%$ & $20,60 \%$ \\
\hline Musyarakah & $14,52 \%$ & $13,64 \%$ & $13,44 \%$ & $12,45 \%$ & $13,61 \%$ \\
\hline
\end{tabular}

Sumber : Statistik Perbankan Syariah, Desember 2014

Tabel 4 Imbal hasil dan margin pembiayaan pada perbankan syariah.

Bank Pembiayaan Rakyat Syariah

\begin{tabular}{|c|c|c|c|c|c|}
\hline $\begin{array}{l}\text { Tahun } \\
\text { Pembiayaan }\end{array}$ & Des 10 & Des 11 & Des 12 & Des 13 & Des 14 \\
\hline Murabahah & $20,07 \%$ & $19,41 \%$ & $23,19 \%$ & $18,27 \%$ & $18,51 \%$ \\
\hline Mudharabah & $19,70 \%$ & $21,02 \%$ & $17,09 \%$ & $16,20 \%$ & $16,46 \%$ \\
\hline Musyarakah & $20,78 \%$ & $21,82 \%$ & $21,20 \%$ & $20,28 \%$ & $20,61 \%$ \\
\hline
\end{tabular}

Sumber : Statistik Perbankan Syariah, Desember 2014

Dari ketiga macam pembiayaan perbankan syariah (Bank Umum Syariah dan Unit Usaha Syariah) yang dilihat dari tabel 3, secara rata-rata imbal hasil dari akad murabahah dalam lima tahun terakhir tidak ada melebihi mudharabah. Tetapi rata-rata melebihi atau diatas imbal hasil akad musyarakah, hanya sekali yang di bawah imbal hasil akad musyarakah, yaitu pada tahun 2014 saja.

Sedangkan pembiayaan pada Bank Pembi-ayaan Rakyat Syariah (BPRS) yang dapat dilihat dari tabel 4 , secara rata-rata imbal hasil dari akad murabahah dalam lima tahun terakhir, hanya ada satu periode melebihi mudharabah dan musyarakah yaitu pada tahun 2012. Tetapi rata-rata melebihi atau diatas imbal hasil akad mudharabah, hanya sekali yang di bawah imbal hasil akad mudharabah, yaitu pada tahun 2011 saja.

\section{Pendapat Tentang Bunga Bank Dalam} Perspektif Sejarah

Secara aktual di masyarakat ada tiga pendapat tentang konsep bunga bank yaitu: membolehkan (halal), ragu-ragu (subhat), dan melarangnya (haram). Bagi yang ragu-ragu (subhat) maka dalam kaidah ilmu figh (prinsip hukum islam) lebih baik ditinggalkan. Bagi yang berpendapat ragu-ragu (subhat) dan melarangnya (haram) sikapnya adalah mencari alternatif konsep tanpa bunga, karena bunga bank adalah identik dengan riba. Sedangkan riba dilarang dalam agama islam.

\section{Pembiayaan Mudharabah}

Secara teknis, mudharabah adalah akad kerjasama usaha antara dua pihak, dimana pihak pertama bertindak sebagai pemilik dana (shahibul maal) yang menye- 
diakan seluruh modal (100\%), sedangkan pihak lainnya sebagai pengelola usaha (mudharib). Keuntungan usaha yang didapat-kan dari akad mudharabah dibagi menurut kesepakatan yang dituangkan dalam kontrak. Jika usaha yang dijalankan mengalami kerugian, maka kerugian itu ditanggung oleh shahibul maal sepanjang kerugian itu bukan akibat kelalain mudharib.Sedangkan mudha-rib menanggung kerugian atas upaya, jerih payah dan waktu yang telah dilakukan untuk menjalankan usaha.Namun, jika kerugian itu diakibatkan karena kelalaian mudharib, ma-ka mudharib harus bertanggungjawab atas kerugian tersebut (Zuhaili, 2009).

\section{Pembiayaan Musyarakah}

Pembiayaan Musyarakah adalah perjanjian dimana terdapat pihak-pihak yang saling menyumbangkan pembiayaan (dana/modal) dan manajemen usaha, pada suatu usaha tertentu dengan proporsi bisa sama atau tidak. Keuntungan/Laba dari usaha pembiayaan musyarakah tersebut dibagi sesuai dengan kesepakatan antara para pihak berdasarkan nisbah yang telah disepakati, demikian juga dengan kerugian yang timbul dari usaha tersebut dibagikan menurut proporsi modal.

\section{Hubungan Dana Pihak Ketiga Dengan Volume Pembiayaan}

Peningkatan jumlah DPK akan menambah jumlah dana yang dapat disalurkan bank untuk pembiayaan termasuk juga pembiayaan mudharabah dan musyarakah. Berdasarkan uraian tersebut diatas, maka dapat dibangun hipotesis penelitian sebagai berikut:

$$
\begin{aligned}
\mathrm{H}_{1.1} \text { : } & \text { Faktor Dana Pihak Ketiga }\left(\mathrm{X}_{1}\right) \\
& \text { berpengaruh terhadap Pembiayaan } \\
& \text { Mudharabah }\left(\mathrm{Y}_{1}\right) \text { pada perbankan } \\
& \text { syariah di Indonesia. } \\
\mathrm{H}_{1.2} \text { : } & \text { Faktor Dana Pihak Ketiga }\left(\mathrm{X}_{1}\right) \\
& \text { berpengaruh terhada Pembiayaan }
\end{aligned}
$$

Musyarakah $\left(\mathrm{Y}_{2}\right)$ pada perbankan syariah di Indonesia.

\section{Hubungan Laba/ Profit Dengan Volume Pembiayaan}

Secara teori dapat dijelaskan bahwa bank dalam menjalankan operasionalnya merupakan sebagai entitas bisnis yang bersifat profit oriented tentu mengaharapkan keuntungan yang tinggi. (Muljono,2006). Bank cenderung akan lebih banyak dalam menyalurkan pembiayaan berbasis bagi hasil, jika laba/ keuntungan yang diperoleh juga besar.

Berdasarkan uraian tersebut di atas, maka dapat dibangun hipotesis penelitian sebagai berikut:

\section{$\mathrm{H}_{2.1}$ : Faktor Laba/ Profit $\left(\mathrm{X}_{2}\right)$ berpengaruh terhadap Pembiayaan Mudharabah $\left(\mathrm{Y}_{1}\right)$ pada perbankan syariah di Indo- nesia. \\ $\mathrm{H}_{2.2}$ : Faktor Laba/ Profit $\left(\mathrm{X}_{2}\right)$ terhadap Pembiayaan Musyarakah $\left(\mathrm{Y}_{2}\right)$ pada perbankan syariah di Indonesia.}

\section{Hubungan NPF Dengan Volume Pem- biayaan}

NPF (Non Performing financing) adalah suatu keadaan di mana nasabah sudah tidak sanggup lagi membayar sebagian atau seluruh kewajibannya kepada bank seperti yang telah diperjanjikan. (Mudrajad \& Suharjonoo, 2002).

Jika hal ini berlangsung terus maka akan berpengaruh terhadap kemampuan bank dalam menyalurkan pembiayaan, dalam hal ini adalah mudharanah dan musyarakah. Berdasarkan uraian tersebut di atas, maka dapat dibangun hipotesis penelitian sebagai berikut :

$\mathrm{H}_{3.1}$ : NPF/ Pembiayaan Macet $\left(\mathrm{X}_{3}\right)$ berpengaruh terhadap Pembiayaan 


\author{
Mudharabah $\left(\mathrm{Y}_{1}\right)$ pada perbankan \\ syariah di Indonesia. \\ $\mathrm{H}_{3.2}$ : NPF/ Pembiayaan Macet $\left(\mathrm{X}_{3}\right)$ \\ berpengaruh terhadap Pembiayaan \\ Musyarakah $\left(\mathrm{Y}_{2}\right)$ pada perbankan \\ syariah di Indonesia.
}

\section{Hubungan Suku Bunga Dengan Volume Pembiayaan}

Harga substitusi dari pembiayaan mudharabah dan musyarakah bank syariah didekati dengan suku bunga kredit bank umum untuk investasi. Commonsensenya semakin tinggi suku bunga kredit, maka masyarakat akan mencari alternatif sumber modal lain. Berdasarkan uraian tersebut diatas, maka dapat dibangun hipotesis penelitian sebagai berikut:

$\mathrm{H}_{4.1}$ : Suku bunga $\left(\mathrm{X}_{4}\right)$ berpengaruh terhadap Pembiayaan Mudharabah $\left(\mathrm{Y}_{1}\right)$ pada perbankan syariah di Indonesia.

$\mathrm{H}_{4.2}$ : Suku bunga $\left(\mathrm{X}_{4}\right)$ berpengaruh terhadap Pembiayaan Musyarakah $\left(\mathrm{Y}_{2}\right)$ pada perbankan syariah di Indonesia.

Hubungan Pembiayaan Berbasis Bagi Hasil (Mudharabah dan Musyarakah) Dengan Biaya Operasional dibanding dengan Pendapatan Operasional (BOPO).

Perbankan syariah memerlukan pengawasan yang baik oleh regulator perbankan.Salah satu indikator penilaian adalah Rasio BOPO yang digunakan untuk mengukur efisiensi operasional bank. Berdasarkan uraian tersebut diatas, maka dapat dibangun hipotesis penelitian sebagai berikut:

$\mathrm{H}_{5.1}$ : Pembiayaan Berbasis Bagi Hasil Mudharabah $\left(\mathrm{Y}_{1}\right)$ berpengaruh Terhadap Rasio BOPO (Z) pada perbankan syariah di Indonesia.

$\mathrm{H}_{5.2}$ : Pembiayaan Berbasis Bagi Hasil Mu- syarakah $\left(\mathrm{Y}_{2}\right)$ berpengaruh Terhadap Rasio BOPO (Z) pada perbankan syariah di Indonesia.

Hubungan secara simultan pengaruh DPK, Profit, NPF, Suku Bunga dan Pembiayaan Bagi Hasil, terhadap Rasio BOPO

Profitabilitas digunakan untuk mengetahui baik buruknya kinerja suatu entitas usaha dalam menjalankan usahanya. Sedang-kan efisiensi kerja operasional perbankan diukur dengan Rasio BOPO.Untuk itu perlu dilakukan penelitian secara simultan dari pengaruh DPK, Profit, NPF, Suku Bunga dan Pembiayaan Bagi Hasil, terhadap Rasio BOPO. Berdasarkan uraian tersebut di atas, maka dapat dibangun hipotesis penelitian sebagai berikut:

H6.1: DPK, Profit, NPF, SB, dan Pembiayaan Berbasis Bagi Hasil Mudharabah $\left(\mathrm{Y}_{1}\right)$ berpengaruh terhadap Rasio BOPO Keuangan Perbankan Syariah (Z) di Indonesia.

$\mathrm{H}_{6.2}$ : DPK, Profit, NPF, SB, dan Pembiayaan Berbasis Bagi Hasil Musyarakah $\left(\mathrm{Y}_{2}\right)$ berpengaruh terhadap Rasio BOPO Keuangan Perbankan Syariah $(Z)$ di Indonesia.

\section{METODE PENELITIAN}

Jumlah Populasi dalam penelitian ini adalah jumlah unit yang dianalisis terdiri dari seluruh perbankan syariah yang ada di Indonesia baik BUS, UUS maupun BPRS. Metode pemilihan sampel yang digunakan adalah purposive sampling, yaitu pemilihan sampel secara tidak acak yang mempunyai tujuan atau target tententu (Indriantoro, 1999). Data yang dikumpulkan meliputi jumlah pembiayaan mudharabah dan musyarakah, Dana Pihak Ketiga (DPK), Laba (Profit), Pembiayaan Macet (NPF), Suku Bunga (SKB) Bank Konvensional dan Rasio BOPO Keuangan Perbankan Syariah. 
Metode analisis yang digunakan dalam penelitian ini adalah metode yang menjelaskan variabel-variabel, baik variabel dependen maupun variabel independen yang ada dalam penelitian.

Statistik deskriptif digunakan untuk mendeskripsikan variabel pembiayaan bagi hasil dalam perbankan syariah dalam bentuk tabel/ grafik dalam laporan tahunan untuk kurun waktu dari bulan Januari 2010 sampai dengan bulan Desember 2014.

Dalam melakukan analisis dan uji hipotesis, prosedur yang dilakukan dibantu dengan menggunakan program komputer yaitu SPSS dan EXCEL menu Tool-PAK. Analisa datayang digunakan dalam penelitian ini adalah analisa regresi linier berganda dengan penaksiran Parameter Regresinya menggunakan metode Ordinary Least Square (OLS).Analisis ini untuk memprediksi nilai dari variabel dependen apabila nilai variabel independen mengalami kenaikan atau penurunan dan untuk mengetahui arah hubungan antara variabel independen berhubungan secara positif atau negatif.

\section{HASIL PENELITIAN}

Obyek penelitian yang digunakan adalah variabel independen yang terdiri dari DPK, Profit, NPF, Suku Bunga dan variabel dependen yaitu pembiayaan berbasis bagi hasil pada perbankan syariah yang ada di Indonesia. berikut:

Adapun kriteria sampel adalah sebagai

1. Laporan Keuangan Bank Umum Syariah (BUS), Unit Usaha Syariah (UUS) dan Bank Pembiayaan Rakyat Syariah (BPRS) yang telah tercatat di Bank Indonesia.

2. Dipublikasikan pada situs www.bi.go.id

3. Periode penelitian bulan Januari 2010 sampai dengan Desember 2014, sehingga diperoleh sampel 60 data.

Analisis deskriptif dilakukan agar dapat memberikan gambaran terhadap variabelvariabel yang digunakan dalam penelitian. Penelitian ini menggunakan empat variabel independen yang bertujuan untuk mengetahui dan menganalisis pengaruh Dana Pihak Ketiga (DPK), Laba (Profit), Pembiayaan Macet (NPF) dan Suku Bunga (SKB) bank konvensional terhadap pembiayaan berbasis bagi hasil. Berdasarkan hasil pengolahan data, diperoleh data perhitungan sebagai berikut:

\section{Tabel 5 Statistik Deskriptif}

\begin{tabular}{lrrrrrrr}
\hline & \multicolumn{7}{c}{ BUS dan UUS } \\
\cline { 2 - 8 } NUMERIK & $\begin{array}{c}\text { DPK } \\
\text { (Milyar) }\end{array}$ & $\begin{array}{c}\text { Laba } \\
\text { (Milyar) }\end{array}$ & $\begin{array}{r}\text { NPF } \\
(\%)\end{array}$ & $\begin{array}{c}\text { Bunga } \\
(\%)\end{array}$ & $\begin{array}{c}\text { Mudharaba } \\
\text { (Milyar) }\end{array}$ & $\begin{array}{c}\text { Musharaka } \\
\text { (Milyar) }\end{array}$ & $\begin{array}{c}\text { BOPO } \\
(\%)\end{array}$ \\
\hline Mean & 126741,34 & 1227,05 & 3,39 & 12,34 & 10978,24 & 26225,53 & 78,52 \\
Minimum & 52811,38 & 83,08 & 2,23 & 11,52 & 6556,28 & 10362,99 & 70,43 \\
Maksimum & 217858,49 & 3443,05 & 4,86 & 13,64 & 14559,44 & 50005,50 & 93,50 \\
Range & 165047,11 & 3359,97 & 2,63 & 2,12 & 8003,16 & 39642,51 & 23,07 \\
Stand Dev, & 126741,34 & 1227,05 & 3,39 & 12,34 & 10978,24 & 26225,53 & 78,52 \\
\hline Sumber : Data sekunder diolah kembali & & & & & &
\end{tabular}




\begin{tabular}{|c|c|c|c|c|c|c|c|}
\hline \multirow[b]{2}{*}{ NUMERIK } & \multicolumn{7}{|c|}{ BPRS } \\
\hline & $\begin{array}{l}\text { DPK } \\
\text { (Juta) }\end{array}$ & $\begin{array}{l}\text { Laba } \\
\text { (Juta) }\end{array}$ & $\begin{array}{l}\text { NPF } \\
(\%)\end{array}$ & $\begin{array}{c}\text { Bunga } \\
(\%)\end{array}$ & $\begin{array}{l}\text { Mudharaba } \\
\text { (Juta) }\end{array}$ & $\begin{array}{l}\text { Musharaka } \\
\text { (Juta) }\end{array}$ & $\begin{array}{c}\text { BOPO } \\
(\%)\end{array}$ \\
\hline Mean & 2561944,30 & 54674,96 & 7,28 & 12,34 & 88767,62 & 319485,50 & 80,19 \\
\hline Minimum & 1283494,70 & 5136,46 & 6,11 & 11,52 & 53283,43 & 136059,96 & 75,20 \\
\hline Maksimum & 4028414,66 & 129279,63 & 8,94 & 13,64 & 124846,82 & 567938,77 & 89,77 \\
\hline Range & 2744919,96 & 124143,18 & 2,83 & 2,12 & 71563,39 & 431878,80 & 14,57 \\
\hline Stand Dev, & 892313,68 & 31893,39 & 0,65 & 0,59 & 21594,00 & 120634,41 & 4,40 \\
\hline
\end{tabular}

Sumber : Data sekunder diolah kembali

Faktor Dana Pihak Ketiga berpengaruh secara signifikan terhadap pembiayaan berbasis bagi hasil mudharabah pada perbankan syariah.

a. Pengaruh Dana Pihak Ketiga terhadap Pembiayaan Mudharabah pada BUS.

Berdasarkan pengujian hipotesis yang menyatakan faktor Dana Pihak Ketiga (DPK) berpengaruh secara signifikan terhadap pembiayaan berbasis bagi hasil mudharabah diterima, ini dibuktikan dengan nilai t hitung sebesar 10,35 dengan signifikansi 0,000 karena $p<0,05$ maka hipotesis diterima.

b. Pengaruh Dana Pihak Ketiga terhadap Pembiayaan Mudharabah pada BPRS. Demikian juga DPK berpengaruh secara signifikan terhadap pembiayaan mudharabah pada BPRS (t hitung 26,834 dengan nilai $p \quad 0,000<0.05)$ maka hipotesis diterima.

Faktor Dana Pihak Ketiga berpengaruh secara signifikan terhadap pembiayaan berbasis bagi hasil musyarakah pada perbankan syariah.

a. Pengaruh Dana Pihak Ketiga terhadap Pembiayaan Musyarakah pada BUS.

Berdasarkan pengujian hipotesis yang menyatakan faktor Dana Pihak Ketiga (DPK) berpengaruh secara signifikan terhadap pembiayaan berbasis bagi hasil musyarakah diterima, ini dibuktikan dengan nilai t hitung 10,909 dengan signifikansi 0,000 karena $p<0,05$.

b. Pengaruh Dana Pihak Ketiga terhadap Pembiayaan Musyarakah pada BPRS.

Demikian juga DPK berpengaruh secara signifikan terhadap pembiayaan musyarakah pada $B^{*}$-PRS (t hitung 20,716 dengan nilai $p \quad 0,000<0.05$ ).

Faktor Laba/profit berpengaruh secara signifikan terhadap pembiayaan berbasis bagi hasil mudharabah pada perbankan syariah.

a. Pengaruh Laba/profit terhadap Pembiayaan Mudharabah pada BUS.

Berdasarkan pengujian hipotesis yang menyatakan faktor Laba/profit berpengaruh secara signifikan terhadap pembiayaan berbasis bagi hasil mudharabah diterima, ini dibuktikan dengan nilai $t$ hitung sebesar 3,819 dengan signifikansi 0,000 karena $p<0,05$ maka hipotesis diterima.

b. Pengaruh Laba/profit terhadap Pembiayaan Mudharabah pada BPRS

Demikian juga laba/profit berpengaruh secara signifikan terhadap pembiayaan mudharabah pada BPRS (t hitung 9,544 dengan nilai $p 0,000<0.05)$.

Faktor Laba/profit berpengaruh secara signifikan terhadap pembiayaan berbasis bagi hasil musyarakah pada perbankan syariah. 
a. Pengaruh Laba/profit terhadap Pembiayaan Musyarakah pada BUS.

Berdasarkan pengujian hipotesis yang menyatakan faktor Laba/profit berpengaruh secara signifikan terhadap pembiayaan berbasis bagi hasil musyarakah diterima, ini dibuktikan dengan nilai t hitung sebesar 2,327 dengan signifikansi 0,024 karena $p<0,05$ maka hipotesis diterima.

b. Pengaruh Laba/profit terhadap Pembiayaan Musyarakah pada BPRS Laba/profit berpengaruh secara signifikan terhadap pembiayaan musyarakah pada BPRS (t hitung 7,11 dengan nilai $p$ $0,000<0.05)$. Besar kecilnya pembiayaan musyarakah yang telah direalisasikan oleh BPRS tergantung besar kecilnya Laba/profit yang dapat dihimpun.

Faktor Pembiayaan Macet/NPF berpengaruh secara signifikan terhadap pembiayaan berbasis bagi hasil Mudharabah pada perbankan syariah.

a. Pengaruh NPF terhadap Pembiayaan Mudharabah pada BUS.

Berdasarkan pengujian hipotesis yang menyatakan faktor NPF berpengaruh secara signifikan terhadap pembiayaan berbasis bagi hasil Mudharabah tidak diterima/ditolak, ini dibuktikan dengan nilai t hitung sebesar $-0,495$ dengan signifikansi 0,623 karena $p>0,05$ maka hipotesis ditolak.

b. Pengaruh NPF terhadap Pembiayaan Mudharabah pada BPRS.

NPF berpengaruh secara signifikan terhadap pembia yaan Mudharabah pada BPRS (t hitung 4,909 dengan nilai p $0,000<0.05)$. Besar kecilnya pembiayaan Mudharabah yang telah direalisasikan oleh BPRS tergantung besar kecilnya NPF.

Faktor Pembiayaan Macet/NPF berpengaruh secara signifikan terhadap pembi- ayaan berbasis bagi hasil Musyarakah pada perbankan syariah.

a. Pengaruh NPF terhadap Pembiayaan Musyarakah pada BUS.

Berdasarkan pengujian hipotesis yang menyatakan faktor NPF berpengaruh secara signifikan terhadap pembiayaan berbasis bagi hasil Musyarakah diterima, ini dibuktikan dengan nilai t hitung sebesar 1,095 dengan signifikansi 0,278 karena $p>0,05$ maka hipotesis ditolak.

b. Pengaruh NPF terhadap Pembiayaan Musyarakah pada BPRS NPF berpengaruh secara sig*-nifikan terhadap pembiayaan Mudharaba pada BPRS (t hitung 7,615 dengan nilai p $0,000<0.05$ ). Besar kecilnya pembiayaan Musyarakah yang telah direalisasikan oleh BPRS tergantung besar kecilnya NPF.

Faktor Suku Bunga berpengaruh secara signifikan terhadap pembiayaan berbasis bagi hasil Mudharabah pada perbankan syariah.

a. Pengaruh Suku Bunga terhadap Pembiayaan Mudharabah pada BUS.

Berdasarkan pengujian hipotesis yang menyatakan faktor Suku Bunga berpengaruh secara signifikan terhadap pembiayaan berbasis bagi hasil Mudharabah tidak diterima/ditolak, ini dibuktikan dengan nilai t hitung sebesar 0,352 dengan signifikansi 0,867 karena $p>0,05$ maka hipotesis ditolak.

b. Pengaruh Suku Bunga terhadap Pembiayaan Mudharabah pada BPRS

Suku Bunga tidak berpengaruh secara signifikan terhadap pembiayaan Mudharabah pada BPRS (t hitung -0,499 dengan nilai $p$ 0,656>0.05) maka hipotesis ditolak.

Faktor Suku Bunga berpengaruh secara signifikan terhadap pembiayaan berbasis bagi hasil Musyarakah pada perbankan syariah. 
a. Pengaruh Suku Bunga terhadap Pembiayaan Musyarakah pada BUS.

Berdasarkan pengujian hipotesis yang menyatakan faktor Suku Bunga berpengaruh secara signifikan terhadap pembiayaan berbasis bagi hasil Musyarakah tidak diterima/ditolak, ini dibuktikan dengan nilai t hitung sebesar 1,169 dengan signifikansi 0,248 karena $p>0,05$ maka hipotesis ditolak.

b. Pengaruh Suku Bunga terhadap Pembiayaan Musyarakah pada BPRS

NPF berpengaruh secara signifikan terhadap pembiayaan Mudharaba pada BPRS (t hitung $-0,054$ dengan nilai $p$ $0,957>0.05$ ). Besar kecilnya pembiayaan Musyarakah yang telah direalisasikan oleh BPRS tidak tergantung besar kecilnya Suku Bunga.

Faktor Pembiayaan Berbasis Bagi Hasil Mudharabah berpengaruh terhadap Ratio BOPO pada perbankan syariah di Indonesia.

a. Pengaruh Pembiayaan Berbasis Bagi Hasil Mudharabah terhadap terhadap Ratio BOPO pada BUS.

Berdasarkan pengujian hipotesis yang menyatakan faktor Pembiayaan Berbasis Bagi Hasil Mudharabah berpengaruh secara signifikan terhadap Rasio BOPO diterima, ini dibuktikan dengan nilai $t$ hitung sebesar -2,490, signifikansi 0,016 karena $p<0,05$ maka hipotesis diterima.

b. Pengaruh Pembiayaan Berbasis Bagi Hasil Mudharabah terhadap terhadap Rasio BOPO pada BPRS.

Pembiayaan Berbasis Bagi Hasil Mudharabah berpengaruh secara signifikan terhadap Rasio BOPO pada BPRS (t hitung $-2,113$ dengan nilai $p 0,039<0.05$ ).

Faktor Pembiayaan Berbasis Bagi Hasil Musyarakah berpengaruh terhadap Rasio BOPO pada perbankan syariah di Indonesia. a. Pengaruh Pembiayaan Berbasis Bagi Hasil Musyarakah terhadap terhadap Rasio BOPO pada BUS.

Berdasarkan pengujian hipotesis yang menyatakan faktor Pembiayaan Berbasis Bagi Hasil Musyarakah berpengaruh secara signifikan terhadap Rasio BOPO diterima, ini dibuktikan dengan nilai $t$ hitung sebesar 1,155 dengan signifikansi 0,253 karena $p>0,05$ maka hipotesis ditolak.

b. Pengaruh Pembiayaan Berbasis Bagi Hasil Musyarakah terhadap terhadap Rasio BOPO pada BPRS.

Pembiayaan Berbasis Bagi Hasil Musyarakah berpengaruh secara signifikan terhadap Rasio BOPO pada BPRS (t hitung 4,610 dengan nilai $p 0,000<0.05$ ). Besar kecilnya pembiayaan Musyarakah yang telah direalisasikan oleh BPRS menentukan besar kecilnya Rasio BOPO.

Faktor DPK, Profit, NPF, Suku Bunga, Pembiayaan Berbasis Bagi Hasil Mudharabah dan Musyarakah berpengaruh terhadap Rasio BOPO Keuangan Perbankan Syariah (Z) di Indonesia.

a. Pengaruh Faktor DPK, Profit, NPF, Suku Bunga, dan Pembiayaan Berbasis Bagi Hasil Mudharabah dan Musyarakah berpengaruh terhadap Rasio BOPO pada BUS.

Berdasarkan pengujian hipotesis yang menyatakan DPK, Profit, NPF, Suku Bunga, Pembiayaan Berbasis Bagi Hasil Mudharabah serta Musyarakah secara bersama-sama berpengaruh secara signifikan terhadap Rasio BOPO diterima, ini dibuktikan dengan nilai $\mathrm{F}$ hitung sebesar 2,713 signifikansi 0,023 karena $p<0,05$ maka hipotesis diterima.

b. Pengaruh Faktor DPK, Profit, NPF, Suku Bunga, dan Pembiayaan Berbasis Bagi Hasil Mudharabah dan Musyarakah berpengaruh terhadap Rasio BOPO pada BPRS. 
Berdasarkan pengujian hipotesis yang menyatakan DPK, Profit, NPF, Suku Bunga, dan Pembiayaan Berbasis Bagi Hasil Mudharabah dan Musyarakah secara bersama-sama berpengaruh secara signifikan terhadap Rasio BOPO diterima, ini dibuktikan dengan nilai $\mathrm{F}$ hitung sebesar 47,734 dengan signifikansi 0,000 karena $p<0,05$ maka hipotesis diterima.

\section{PENUTUP}

Berdasarkan hasil analisis maka kesimpulan yang diambil dari penelitian ini adalah sebagai berikut:

1. Terdapat pengaruh DPK terhadap pembiayaaan berbasis bagi hasil mudharabah pada kedua lembaga perbankan syariah di Indonesia.

2. Terdapat pengaruh DPK terhadap pembiayaaan berbasis bagi hasil musyarakah pada kedua lembaga perbankan syariah di Indonesia.

3. Terdapat pengaruh laba terhadap pembiayaaan berbasis bagi hasil mudharabah pada kedua lembaga perbankan syariah di Indonesia.

4. Terdapat pengaruh laba terhadap pembiayaaan berbasis bagi hasil musyarakah pada kedua lembaga perbankan syariah di Indonesia.

5. Tidak terdapat pengaruh NPF/pembiayaan macet terhadap pembiayaan berbasis bagi hasil mudharabah pada BUS di Indonesia. Akan tetapi NPF berpengaruh signifikan terhadap pembiayaaan berbasis bagi hasil mudharabah pada BPRS.

6. Tidak terdapat pengaruh NPF/pembiayaan macet terhadap pembiayaan berbasis bagi hasil musyarakah pada BUS di Indonesia. Akan tetapi NPF berpengaruh signifikan terhadap pembiayaan berbasis bagi hasil musyarakah pada BPRS.
7. Tidak terdapat pengaruh suku bunga terhadap pembiayaaan berbasis bagi hasil mudharabah pada perbankan syariah di Indonesia.

8. Tidak terdapat pengaruh suku bunga terhadap pembiayaan berbasis bagi hasil musyarakah pada perbankan syariah di Indonesia.

9. Terdapat pengaruh pembiayaaan berbasis bagi hasil mudharabah dan musyarakah terhadap rasio BOPO pada kedua lembaga perbankan syariah di Indonesia.

Berdasarkan pembahasan dan kesimpulan hasil penelitian ini maka implikasi penelitian ini adalah sebagai berikut:

1. Perbankan syariah lebih mengupayakan peningkatan dana pihak ketiga dan laba perbankan syariah dana pihak ketiga memberikan pengaruh yang besar. Peningkatan jumlah dana pihak ketiga akan menambah jumlah dana yang dapat disalurkan bank untuk pembiayaan bagi hasil sehingga dapat meningkatkan pendapatan. Peningkatan pendapatan yang besar akan menambah besar laba bank syariah yang pada akhirnya juga akan menambah jumlah pembiayaan bagi hasil yaitu pembiayaan mudharabah dan musyarakah.

2. Perbankan syariah perlu melakukan sosialisasi sekaligus memberikan pengetahuan kepada masyarakat tentang produk penghimpunan dana terutama yang menggunakan prinsip bagi hasil. Peningkatan dana dari investasi ini dapat dialokasikan untuk meningkatkan pembiayaan mudharabah dan musyarakah yang disalurkan oleh perbankan syariah.

Penelitian yang dilakukan oleh peneliti masih ada beberapa keterbatasan antara lain:

1. Sampel yang diteliti masih relatif sedikit jika dibandingkan dengan periode lama beropera- 
sinya perbankan syariah di Indonesia, yaitu hanya 60 bulan selama periode penelitian 5 tahun, hasil penelitian mungkin akan berbeda jika dalam mengambil sampel dengan jangka waktu yang lebih panjang, sehingga akan diperoleh data yang lebih banyak dari penelitian ini.

2. Peneliti hanya mengambil empat variabel independen, yaitu variabel Dana Pihak
Ketiga, Laba, Pembiayaan macet/ NPF dan Suku Bunga. Masih banyak variabel lain yang mempengaruhi pembiayaan berbasil bagi hasil, baik faktor internal maupun faktor eksternal. Untuk penelitian selanjutnya diharapkan dapat menggunakan variabel lain, selain variabel dalam penelitian ini.

\section{REFERENSI:}

Al-Qur'an dan terjemahannya, 2010.Departemen Agama Republik Indonesia.

Andriyanti, 2010. Faktor-Faktor yang Mempengaruhi Jumlah Penghimpunan Dana Pihak Ketiga (Deposito Mudharabah 1 Bulan) Bank Muamalat Indonesia (BMI), Makalah Simposium Nasional Akuntansi, Unsoed Purwokerto.

Antonio, 2001. Optimalisasi pembiayaan bagi hasil sebagai upaya Memberdayakan UMKM yang berkeadilan. Makalah Undip Semarang.

Bank Indonesia, 2014. Statistik Perbankan Syariah. www.bi.go.idkumpulan data Bank Umum Syariah (BUS) dan Unit Usaha Syariah (UUS) serta Bank Perkreditan Rakyat Syariah (Lapbul BPRS)disusun bersumber dari laporan BUS-UUS sesuai dengan PBINo.15/4/PBI/2013 tentang Laporan Stabilitas Moneter dan Sistem Keuangan Bulanan Bank Umum Syariah dan Unit Usaha Syariah.

CecepK. Halim, 2000. Sistem Perbankan Syariah di Indonesia dalam Perspektif Fikih Ekonomi, Fajar Media Press, Yogyakarta.

Gilang Nur, Giannini, 2013. Analisis Pengaruh Rasio Keuangan Dan Tingkat Bagi Hasil Terhadap Pembiayaan Mudharabah Pada Bank Umum Syariah di Indonesia. Karya IImiah. Fakultas Ekonomi, Universitas Indonesia.

IAI-PSAK, 2007. Pernyataan Standar Akuntansi Keuangan Nomor 105 Tentang Akuntansi Mudharabah, IAI Jakarta.

IAI-PSAK, 2007. Pernyataan Standar Akuntansi Keuangan Nomor 106 Tentang Akuntansi Musyarakah, IAI Jakarta.

Myers H Raymond ,1997.A First Course In The Theory of Linier Statistical Models, PMS Kent Publishing Company Boston.

Nasution Anwar, 23 Juli 2015.Yunani dan Indonesia, Harian Kompas, Amanat Hati Nurani Rakyat . Jakarta.

Nurul Khikmah,2015, Analisis Pengaruh ROA, BOPO, NPF dan FDP Terhadap Tingkat Bagi Hasil Mudharabah, Universitas Negeri Sunan Kalijaga, Yogyakarta.

Suliyanto, 2010. Panduan Pratikum Analisis Statistik : Alat Analisis dalam Aplikasi Penelitian. Program Pasca Sarjana Magister Sains Ekonomi Manajemen, Universitas Jenderal Sudirman, Purwokerto.

Suharjo Bambang, 2013. Statistika Terapan, Graha Ilmu, Yoygyakarta.

Seputar Berita Ekonomi, 2014. Ekonomi Makro Indonesia.

Syafi'i, Antonio Muhammad, 2001. Bank Syariah ; Dari Teori ke Praktik,

Gema Insani Press, Jakarta.

- 2002. Bank Syariah ; Dari Teori ke Praktik, Gema Insani Press, Jakarta

2003. Bank Syariah ; Dari Teori ke Praktik, Gema Insani Press, Jakarta

Yafiany Siti, 2013. Analisis Pengaruh Manajemen Risiko Pembiayaan Terhadap Kinerja, Studi Kasus Pada Bank Syariah Mandiri. Penelitian Ilmiah,Fakultas Ekonomi, Universitas Indonesia.

Zainol Zairi and Salina Kassim, 2012.A critical review of the literature on the rate of return risk in Islamic banks. International Journal of Islamic Accounting and Business Research. Volume 3, Issue 2.

Zuhaili, 2009.Analisis Implementasi Prinsip-prinsip Perjanjian Akad Mudharabah Pada Baitul Maal Wat Tamwil (BMT) Tumang Boyolali, Universitas Sebelas Maret Surakarta

http://nurazifah.blogspot.com/2012/05/percepatan-pertumbuhan-bank-syariah, hatml, Diakses 15 Nopember 2012 